\title{
Fire-resistant Characteristics of Traditional Buildings in Urban Historic Districts
}

\author{
Pei-Chun Shao ${ }^{1 *}$ and Chun-Hao Shao ${ }^{2}$ \\ ${ }^{1}$ Associate Professor, Dept. of Land Management and Development, Chang Jung Christian University, 71101 Tainan City, Taiwan \\ (R.O.C.) \\ ${ }^{2}$ Assistant Professor, Graduate School of Disaster Management, Central Police University, 33304 Taoyuan City, Taiwan (R.O.C.)
}

\begin{abstract}
The fire-resistant quality of brick walls of the buildings in historic districts was investigated in this study. A review of the available literature, data application by simulation of fire dynamics, and experiments involving three types of brick walls with reference to the ISO834 temperature-time curve were utilized to ascertain the possibility of a fire spreading through the brick walls of historic buildings having vulnerable construction. The results demonstrated that smoke and combustion due to the heat penetrated through the clefts on the damaged exposed side of the brick walls or due to the inefficacy and cracks in the fireproofing material used. To prevent the decline of antique historic or old buildings, it is necessary to consider the reinforcement of the fire-resistant characteristics of their walls. Besides, concerted efforts need to be put in to educate the residents regarding fire safety along with a comprehensive fire safety management planning strategy for historic districts.
\end{abstract}

\section{Introduction}

Historic districts, located in urban areas which were developed earlier, are usually identified with cultural heritage that could be traced back to ancient times prior to urban development. The maintenance of the landscape and protection of the entire environment of these regions has become an important global issue and likewise in Taiwan. Historic districts are usually characterized by narrow streets (Fig. 1), high density of old buildings, and vacant housing. Several historic buildings have been destroyed by fire (Fig. 2) in such areas in Taiwan recently and an improvement in the process of fire safety management is needed. To implement adequate fire safety measures and reduce the risk of fire in old buildings and their environment, it is necessary to strengthen fire rescue services and spread an awareness among the residents to practice fire-resistance operations for preservation of the environment.

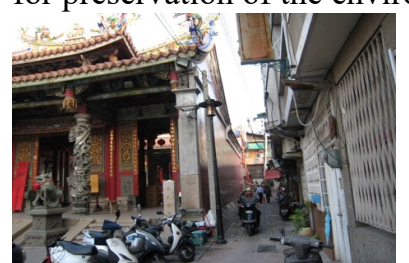

Fig. 1. Historic building in a narrow street Source: Taken by author

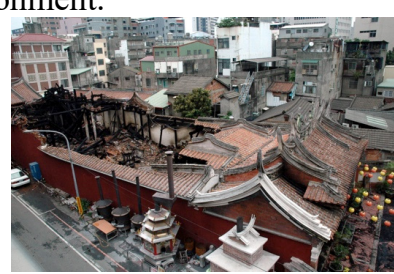

Fig. 2. Historic temple destroyed by fire Source: Epoch times, April 10 $0^{\text {th }}, 2006$
In Taiwan, the preservation of historic districts was included in the Act of Cultural Treasure Protection since 2005 and 11 historic districts were certified under this Act in Taiwan until 2013. A review of the literature related to fire safety management was carried out to understand the risk of fire spreading in historic districts and fire-resistant tests for building materials were developed as a methodology by utilizing the data obtained from field surveys and simulation of fire dynamics in a historic building. The goal of this study was to assess the fire-spreading conditions and fireresistant status of a building to form the basis for fire safety management measures for historic districts.

\section{Research on risk of fire and fire simulation in historic districts}

In this section, a review of the literature related to risk of fire, fire simulation and fire experiments in historic buildings is presented.

\subsection{Risk of fire in historic districts}

Many historic districts are located in southern Taiwan, especially in Tainan city. In the Chihkan historic district of Tainan city, the old buildings are made of bricks, wood, bricks with wooden panels or bricks with galvanized iron sheets. The risk of fire is related to the extent of usage of the building, building materials, and the width of the alleys in the inner blocks of the historic districts. An alley of a width within two meters would obstruct rescue operations by fire engines and firefighters. In addition to narrow alleys, other vulnerable factors preventing fire safety include the usage of old electronic instruments, illegal parking of motorcycles or bicycles, causing obstruction to rescue

\footnotetext{
* Corresponding author: peicshao@mail.cjcu.edu.tw
} 
operations, and low awareness regarding fire safety among the residents in Chihkan historic district of Tainan city in Taiwan [1]. Despite the vulnerability of the physical environment, imparting fire safety instructions to residents, or conducting firefighting drills, would possibly develop fire safety in such areas [2]. In traditional villages located in the mountains in Korea, historic buildings, such as old temples, are threatened by wild fire and depending on the types and characteristics of trees surrounding these buildings that would be able to prevent the fire from spreading; a fire risk map for wild fire was proposed [3]. Research on fire related to historic districts in Japan indicated that self disasterprevention teams formed by communities, firefighting techniques and fire block zones developed by local characteristics of building usage would reduce the risk of fire [4].

\subsection{Utilization of fire simulation}

In Japan, historic districts are characterized by a high density of traditional wooden buildings, thus, researchers have developed fire simulation programs to study the potential fire-spreading areas in historic districts in Kyoto city and to compare the results of the fire simulation with the areas destroyed after the Sakata conflagration [5][6]. Based on the simulation, the relationship between the risk of fire and building materials or the correlation between the spreading of fire and the lay-out of a building was examined and proved to be helpful in arranging firefighting resources and preparing a cultural treasure rescue plan for historic buildings. To propose fire safety planning for historic districts in Kanazawa city of Japan, a study also illustrated the application of fire simulation to identify rescue areas by arrangement of fire hydrants, stonewall and streets [7]. Besides, higher ratios of fire resistance, seismic resistance and arrangement of hydrants would lead to a high fire-prevention efficiency for the historic district in Kyoto city [8]. In Taiwan, brick is a common material used in historic buildings and it seldom causes wide-area conflagration. However, the spreading of fire is usually related to the areas surrounding a building on fire. As a result of research conducted on the spreading of fire in the Chihkan Cultural Zone by means of an urban fire-spreading model, it was found that a wooden building next to a burning one would be affected by fire easier than a brick construction building, depending on the speed of the wind and the simulation showed that conflagration did not occur [9]. Furthermore, a fire dynamics simulator (FDS) was also utilized to understand the behavior of fire and smoke within a historic building. From the results of the simulation, it was determined that the smoke gathered on the roof and would be difficult to dissipate due to the shape of the space within the building; besides, the high temperature of smoke on the roof would destroy the cultural treasures placed on the roof and the time taken for the smoke to gather could be set as the time limit for the firefighting activity [10].

\subsection{Fire experiments and fire-mitigation planning}

The fire experiments to be conducted in historic districts were divided into two types, namely, a fire-resistant test of materials and a small-scale artificial street model of a traditional area. Yasui, Hasemi et al. applied the standards of ISO834 to set up a small-scale experiment on a wooden/soil wall of a traditional wooden construction to show how a soil wall with plastering on both sides, and the thickness and hydrous ratio of the soil layer affect the fire-resisting characteristics [11]. Himoto et al. carried out a small-scale experiment involving an artificial block model to understand the spreading of fire in the traditional streets of Kyoto city in Japan. The results showed that the types of fuel, frontal road, flame shape and design of the external wall of a building affected the spreading of fire [12]. Shao utilized mobile water pipes and electronic water jets as simple firefighting instruments and tested their firefighting performance to illustrate the flexible using principle [13].

\section{Fire-resistance experiments}

To sum up the literature analysis above, the fire-resistant experiments for a brick wall are illustrated in this section.

\subsection{Issues related to fire simulation of traditional buildings}

The experiment was based on the results of the research related to the "Shengnong Street" located in Old Five Channels Cultural Zone of Tainan city to understand the relationship between the spreading of fire and fire resistance in the historic building [14]. According to a field survey of Shengnong Street, shown in Fig. 4, approximately $60 \%$ of the buildings are of brick-wood construction (Fig. 3). "Kinghwafu", a historic temple of brick-wood construction on the street, was certified as a heritage site (Fig. 5). To analyze the behavior of fire in the historic temple, simulation of fire dynamics was carried out with hypothetical flammable materials placed in the center of the temple, such as joss sticks and candles, and the rate of heat release was set at $500 \mathrm{kw} / \mathrm{m}^{2}$. According to the results of the FDS (Fire Dynamics Simulator developed by NIST, U.S.) in the historic temple, obtained from the literature, the highest temperature measured by the thermocouple at Point 1 near the fire source and roof was approximately $1400^{\circ} \mathrm{C}$ in $600 \mathrm{~s}$ of computing time (Fig. 6) [15]. The buildings adjoining both sides of the historic temple were also of brick-wood construction and the fire-resisting performance of the brick walls between them could become a key factor in the spreading of the fire. Thus, the experiment was designed to assess the heat penetration through the brick walls at high temperatures. 


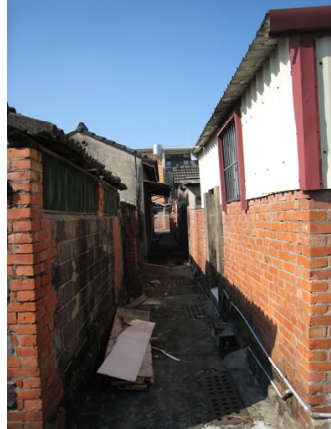

Fig. 3. Style of traditional building of wood-brick construction

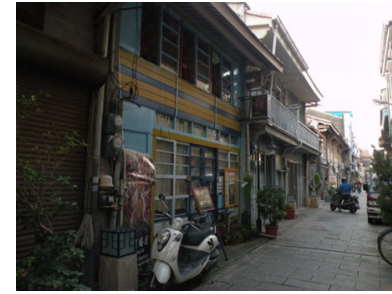

Fig. 4. A view of Shengnong street

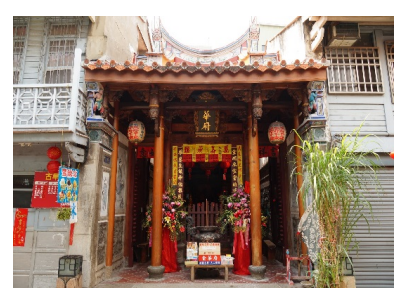

Surroundings of heritage temple-Kinghwafu
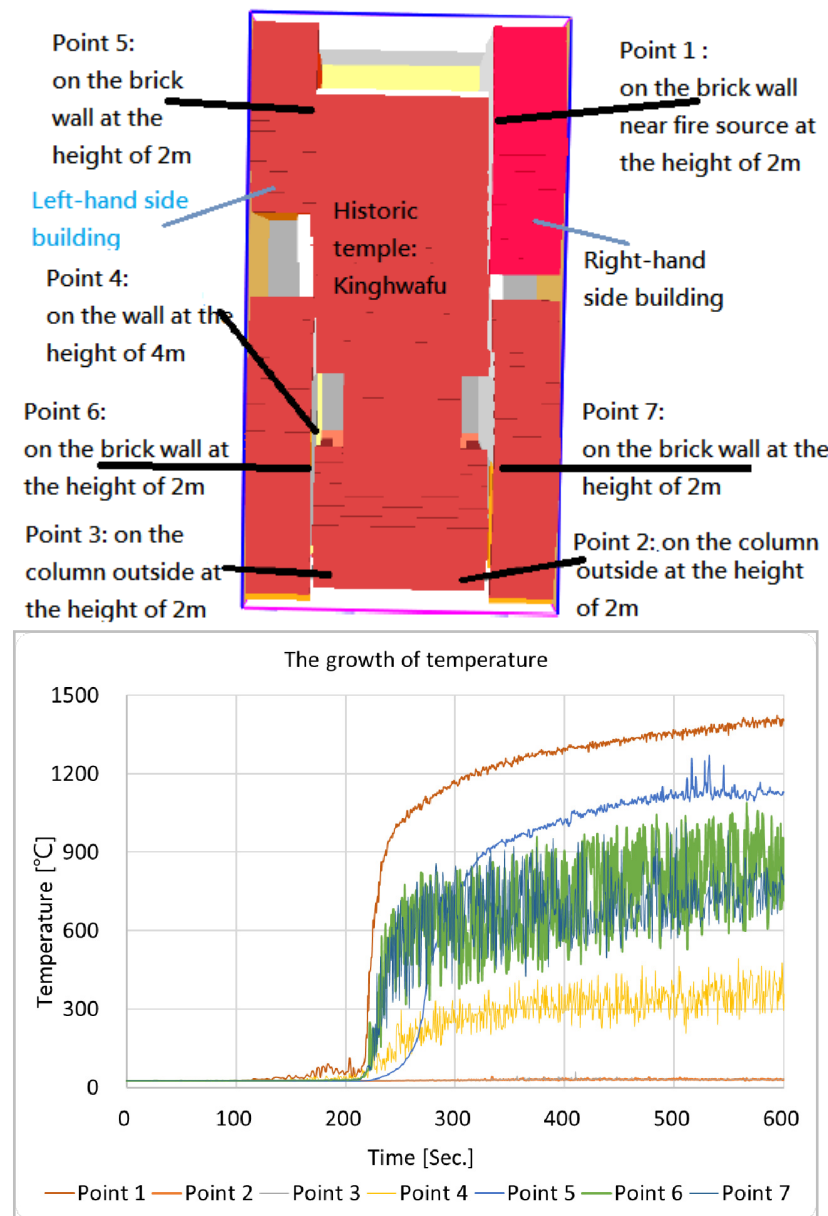

Fig. 6. Location of thermocouples and temperature growth curve of each point

\subsection{Design of the experiments}

According to the field survey, plywood panels were commonly utilized as decorating materials in the interiors of old buildings. Thus, there were three samples of brick walls for conducting experiments with reference to the standard ISO 834 time-temperature curve: bare brick wall, brick wall with plywood panel and brick wall with calcium silicate board for comparing with the plywood panel. The sizes and characteristics of the samples are given in Table 1 and their images (Type 1 to Type 3) before the test are shown in Table 2.

Table 1. Size and characteristics of samples for experiments

\begin{tabular}{|l|l|l|}
\hline Type of sample & $\begin{array}{l}\text { Length } \times \text { Width } \times \\
\text { Thickness }(\mathrm{cm})\end{array}$ & $\begin{array}{l}\text { Test time } \\
(\mathrm{min} .)\end{array}$ \\
\hline $\begin{array}{l}\text { Type 1: Bare brick } \\
\text { wall }\end{array}$ & Brick wall: $100 \times 100 \times 20$ & $\begin{array}{l}60(\text { To be } \\
\text { interrupted } \\
\text { at the 40 } \\
\text { min })\end{array}$ \\
\hline $\begin{array}{l}\text { Type 2: Brick wall } \\
\text { with plywood } \\
\text { panel }\end{array}$ & $\begin{array}{l}\text { Brick wall: } 100 \times 100 \times 20 \\
\text { Plywood panel (unexposed } \\
\text { side): } 100 \times 100 \times 3\end{array}$ & 60 \\
\hline $\begin{array}{l}\text { Type 3: Brick wall } \\
\text { with plywood } \\
\text { panel and calcium } \\
\text { silicate board }\end{array}$ & $\begin{array}{l}\text { Brick wall: } 100 \times 100 \times 20 \\
\text { Plywood panel (unexposed } \\
\text { side): } 100 \times 100 \times 3 \\
\text { Calcium silicate board: } \\
100 \times 100 \times 1.2\end{array}$ & 60 \\
\hline
\end{tabular}

Table 2. A view of samples Type 1 to Type 3 before the fire test

\begin{tabular}{|l|l|l|l|}
\hline $\begin{array}{l}\text { Type of } \\
\text { sample }\end{array}$ & $\begin{array}{l}\text { Unexposed side } \\
\text { before test }\end{array}$ & $\begin{array}{l}\text { Exposed side before } \\
\text { test }\end{array}$ \\
\hline $\begin{array}{l}\text { Type 1. Bare } \\
\text { brick wall }\end{array}$ & & & \\
\hline $\begin{array}{l}\text { Type 2. Brick } \\
\text { wall with } \\
\text { plywood panel }\end{array}$
\end{tabular}

The test was carried out in northern Taiwan where the average temperature is $16.5^{\circ} \mathrm{C}$. The sample was mounted on a vertical wall furnace, and thermocouples were placed at fifteen points, namely, four points on the exposed side and eleven on the unexposed side of the three samples to measure the temperature, and the time for the test was 60 minutes. Fig. 7 shows the locations of the thermocouples on the unexposed side. 


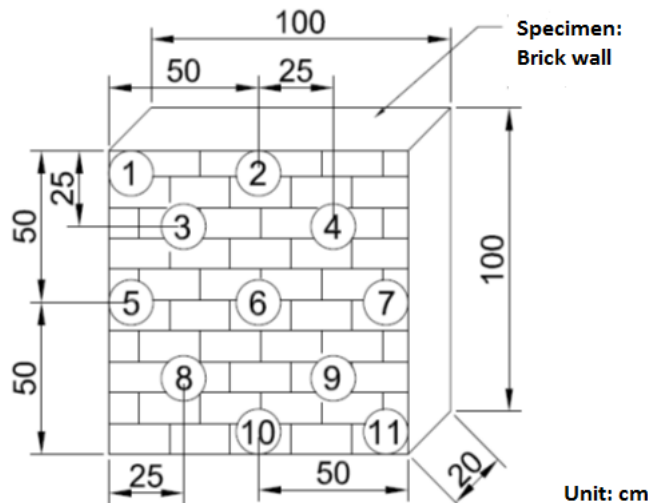

Fig. 7. Location of thermocouples on the unexposed side

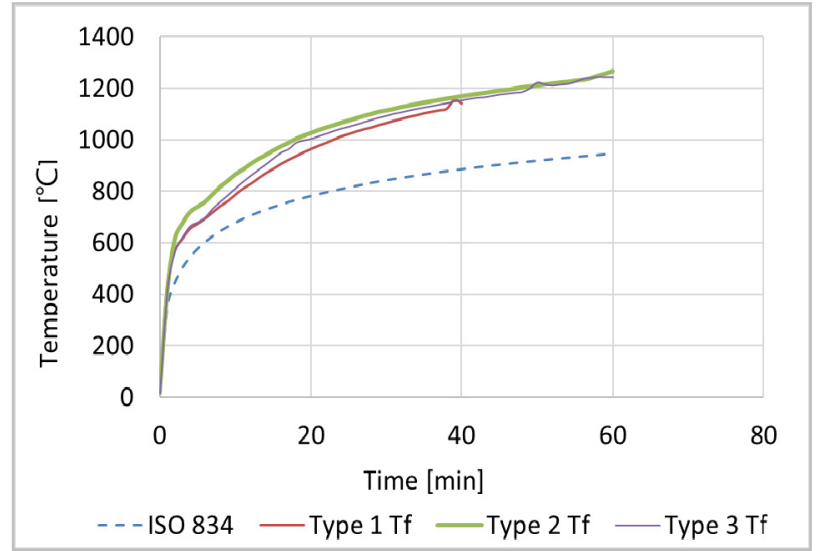

Fig. 8. Average temperature of furnace

\section{Discussion of experiments}

The average temperature of the furnace in the fireresistant tests for Types 1 to 3 of the samples is shown in Fig. 8. It can be seen that, the data of the experiments showed higher temperatures as compared to the ISO834 standard curve. It may be surmised that the water content of the samples and ventilation affected the results. The three test results can be summarized as follows: The temperature of the Type 2 sample is higher than that of the samples Type 1 and Type 3 due to the unexposed side being covered by the plywood panel, as the heat penetrated to reach the plywood by partial combustion. On the other hand, in the case of the Type 3 sample, the calcium silicate board could obstruct the heat to reduce its penetration to the unexposed side.

\subsection{Type 1: Bare brick wall}

The temperature-time curves of the Type 1 sample are shown in Fig. 9. The highest temperature at Point 1 on the unexposed side reached $30.8^{\circ} \mathrm{C}$ ten minutes after starting the heating process. As the temperature increased, the fireproofing material on the furnace collapsed and detached the thermocouples at the $40^{\text {th }}$ minute, hence, the test was interrupted. Simultaneously, Point 2 reached the highest temperature of $104{ }^{\circ} \mathrm{C}$; high temperatures were also shown at Points 1, 5 and 4, which were $99^{\circ} \mathrm{C}, 76^{\circ} \mathrm{C}$ and $72.4^{\circ} \mathrm{C}$, respectively. At this moment, the average temperature of the furnace was over $1110^{\circ} \mathrm{C}$. Some cracks and broken parts were found on the exposed side after the test. The vulnerable cracks were behind the thermocouples at Points 1, 2, 4 and 5 of the higher measured temperatures ( Fig. 10). The reasons could be that the vulnerability already existed in the brick or the Sto Mineral wool, which was placed to obstruct the heat, was destroyed and the heat penetrated the brick due to the high temperature during the test.

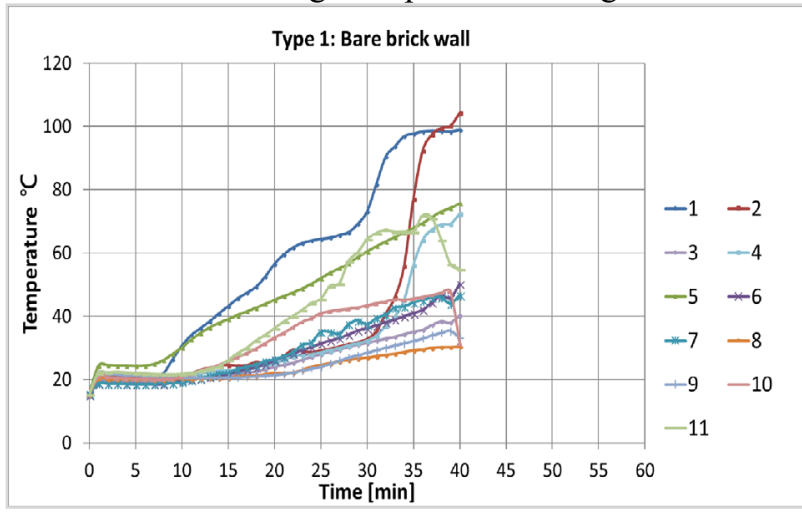

Fig. 9. Temperatures of the unexposed side of Type 1 sample

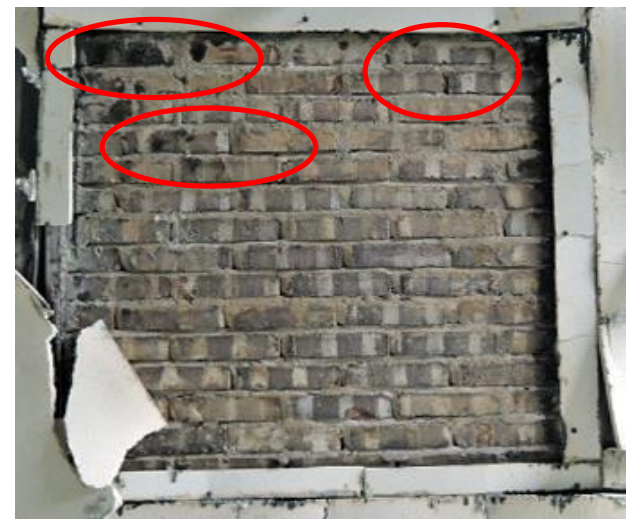

Fig. 10. Locations of cracks marked in red in the case of Type 1 sample

\subsection{Type 2: Brick wall with plywood panel}

The temperature-time curves of the Type 2 sample are shown in Fig. 11. Smoke appeared at the $26^{\text {th }}$ minute and the color of the plywood panel turned to brown; partial combustion occurred at the $39^{\text {th }}$ minute at Point 11 marked in Fig. 12. Within the one-hour test, the highest temperature recorded at Point 11 was $314^{\circ} \mathrm{C}$; Points 1 and 2 also showed high temperatures of $250^{\circ} \mathrm{C}-265^{\circ} \mathrm{C}$. According to the ISO834, the average temperature of the unexposed side could not exceed $156^{\circ} \mathrm{C}-186^{\circ} \mathrm{C}$ in this case, hence, the results of this test could not satisfy the criteria of insulation against fire. The reasons could be that the fireproofing material between the furnace and unexposed side was not appropriate enough or was destroyed by the strong heat, and the fire spread directly to the unexposed side. 


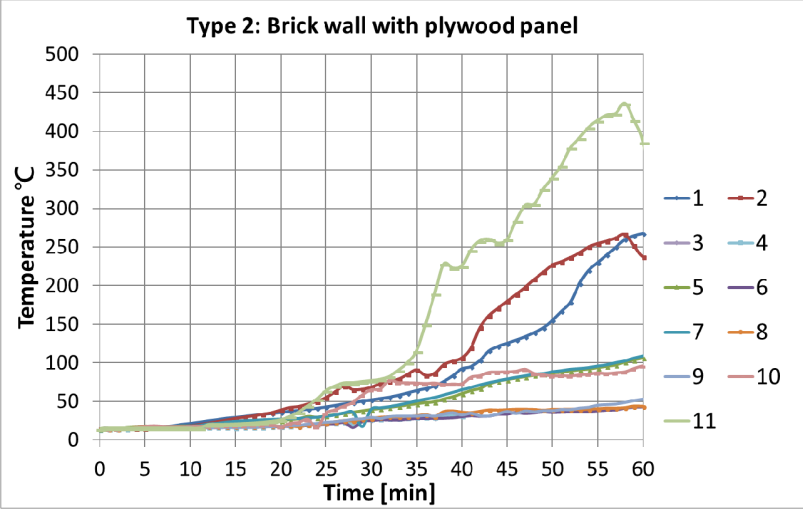

Fig. 11. Temperatures of the unexposed side of Type 2 sample

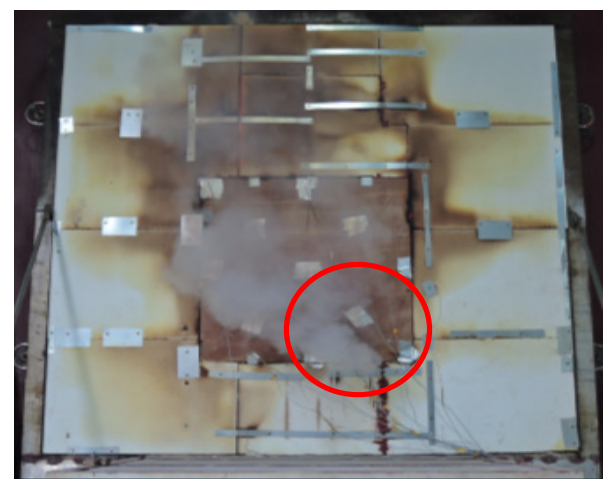

Fig. 12. Smoke and combustion on the unexposed side

\subsection{Type 3: Brick wall with plywood panel and calcium silicate board}

The temperature-time curves of the Type 3 sample are shown in Fig. 13. The temperature at any point on the unexposed side did not exceed $100^{\circ} \mathrm{C}$ within the 60 minute test for the sample of Type 3 (Fig. 13). Hence, it can be considered that the simple calcium silicate board with a thickness of $1.2 \mathrm{~cm}$ efficiently obstructed the heat. The color of the fireproofing panel on the upper and lower parts of the specimen, marked in Fig. 14, turned to brown due to the high temperatures. Combustion of the unexposed side did not occur in this test.

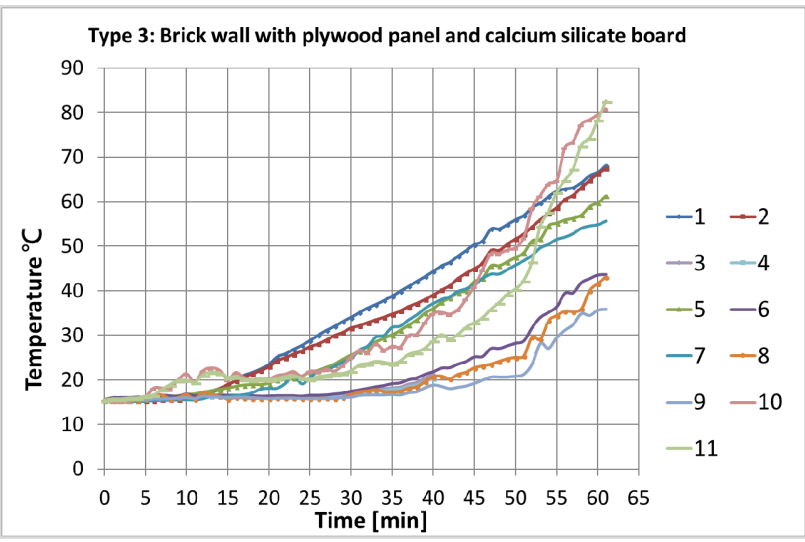

Fig. 13. Temperatures of the unexposed side of Type 3 sample

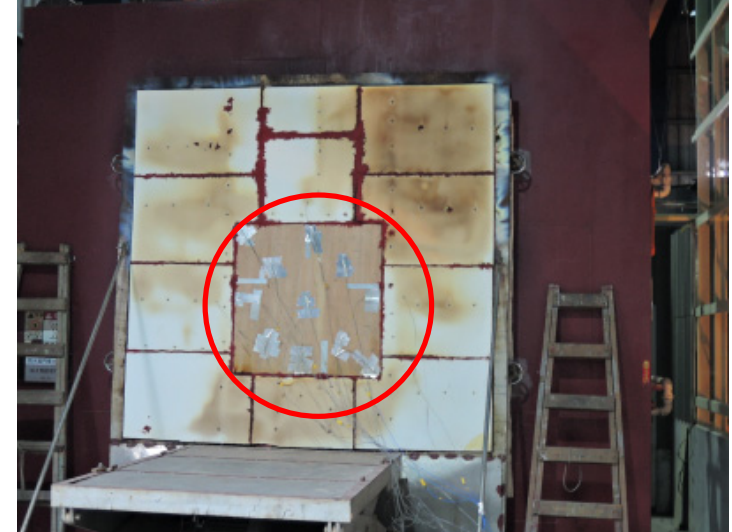

Fig. 14. Almost no smoke or combustion on the unexposed side

The results of the three tests showed that brick walls could be destroyed if the bricks were vulnerable to heat and lacked purity and the fireproofing material was inadequate against fire insulation. In the fire dynamics simulation in the historic temple Kinghwafu, the highest temperature of about $1400^{\circ} \mathrm{C}$ was recorded, therefore, the brick wall could be destroyed under the high temperature and heat could penetrate easily due to the weakness in the construction of the antique building. On the other hand, the temperature at Point 1 was $100^{\circ} \mathrm{C}$ at the $40^{\text {th }}$ minute in the test of the Type 2 sample, while for the Type 3 sample, at the same time, Point 1 showed a temperature of $45^{\circ} \mathrm{C}$ on the unexposed side (Figs. 11 and 13). This indicates that a simple calcium silicate board of thickness of $1.2 \mathrm{~cm}$ could indeed reduce the penetration of heat. Thus, repair of antique brick walls and strengthening the fire-resistant properties of constructions, such as optimum fire insulation, fire integrity and stability of brick walls of historic buildings could reduce the risk of spreading of fire and the burden of firefighting operations in such traditional and fireprevention vulnerable districts.

\section{Conclusion}

High density of old/traditional buildings of brick-wood construction is the characteristic feature of historic districts. In addition, many of the old buildings adjoin each other, therefore, the resistance to fire of such buildings was investigated in this study. With the help of available literature, the data obtained through a fire dynamics simulator, implemented in the historic temple Kinghwafu, was applied to understand the resistance to fire behavior in the temple. Based on the high temperatures achieved in the FDS in the temple, three types of brick walls were tested with the ISO834 temperature-time curve as a reference, to determine the fire resistance of a brick wall. The results were indicative of rifts on the exposed side; besides, the heat penetrated the brick wall due to inadequate and damaged fireproofing materials to give rise to smoke and combustion of the plywood panel on the unexposed side. With a calcium silicate board set on the exposed side, the fire insulation could be improved and the temperature on the unexposed side controlled without exceeding $100^{\circ} \mathrm{C}$. Though a brick wall is incombustible, its decline in 
antique or old historic buildings could make them vulnerable against fire.

The findings of this research provide a basic vision on the reinforcement of fire-resistant properties of brick walls of buildings in historic districts. Besides, for implementation of fire safety management measures, the cost of reinforcement of fireproofing materials should be affordable. Simultaneously, awareness of fire safety also needs to be widely spread among the residents, especially the elders, who form the majority of residents in the historic districts. The process of increasing the efficiency of firefighting and rescue activities by conducting training sessions or imparting instructions would be an important issue in the preservation of historic districts in the future.

This research was funded by the Ministry of Science and Technology, Taiwan, Project No. 103-2625-M-309002. The author is also grateful to Mr. Hsuen-Han Lin for his support in carrying out the survey and many persons' assistants in preparing experiments.

\section{References}

1. Shao, P., Tanaka, T. and Chien, S., "Fire Safety Planning for Heritage and Historic Buildings of Cultural Zone in Tainan City," Report of Cultural Bureau of Tainan City, Taiwan (2010)

2. Shao, P., "Risk Communication applied to Community-Based Fire Mitigation and Management for Historic Areas," Fire Science and Technology 2015, Springer, pp. 383-394 (2016)

3. Lee, J. and Kim, D., Developing Heat Flux Evaluation and Fire Risk Map for Forest Fires in Yangdong Villages, Journal of KOSHM, 14(5), 19-25 (2014)

4. Imoto, S., Okubo, T., Himoto, K. and Tanaka, T. "A Study on the site Planning of the Water shield system for Protecting Wooden Cultural City: Evaluation of Its Effectiveness by Using Fire Spread Model-case study in Kiyomizu area, Kyoto," Journal of Disaster Mitigation of Cultural Heritage and Historic Cities, 4, 21-28. (2010)

5. Oura, M., Himoto, K. and Tanaka, T., "Fire spread simulation in Sakata: Verification of Physically-based Model for Urban Spread Fire," Technical Paper of Annual Meeting, Architectural Institute of Japan, pp. 355-356 (2005)

6. Himoto, K. and Tanaka, T., Development of a Physics-based Urban Fire Spread Model, Journal of Environmental Engineering of Architectural Institute of Japan, 607,15-22 (2006)

7. Masuta, T. and Nagano, S., "Simulation Analysis on Large-scale Fires of Wooden House in Urban Area of Kanazawa City", Technical Paper of Annual Meeting, Architectural Institute of Japan, pp.3-4 (2012)
8. Ishizuka, M., Hasemi, Y., Yasui, N. and Ikeda, S. "Study of the Disaster Readiness Means for Historical Area surrounding Important Cultural Property Buildings," Technical Paper of Annual Meeting, Architectural Institute of Japan, pp.6972 (2012)

9. Shao, P. and Yeh, T., Fire-Safety Planning for Early-developed Urban Region: A Case Study of Tien-Hou Community of Tainan City in Taiwan, Journal of International City Planning 2010, pp.723-737 (2010)

10. Shao, P. "Study on Fire-risk Assessment for Historic Area of Tainan city in Taiwan: application of Fire Simulation and Experiments of Simple Fire-fighting Equipment," Proceedings of the $2^{\text {nd }}$ Asia Conference on Urban Disaster Reduction, Disaster Management Society of Taiwan, CD-Version (2014)

11. Yasui, N., Hasemi, Y. and et al. Influences of Construction Details on The Fire Resistance of Traditional Wood/ Soil Walls, Journal of Environmental Engineering of Architectural Institute of Japan, 567,7-13 (2003)

12. Himoto, K., Deguchi, Y. Tsuchihashi, N. Experiment for Fire Spread in Narrow Alleys in Historic Districts, Proceedings of Annual Meeting, Japan Association of Fire Science and Engineering, pp.280-281 (2013)

13. Shao, P. "Extinguishing Efficient for Simple Firefighting Equipment: In a Case of Car Washer," Proceedings of Annual Meeting, Japan Association of Fire Science and Engineering, pp.152-153 (2013)

14. Shao, P. "Study on firefighting Energy for Traditional Building's Fire in Historic District (I)" Report MOST103-2625-M-309-002, Taiwan, 32P (2014).

15. Shao, P. and Lin, H. "Analysis of Fire Simulation for Heritage Building in Historic Area," Proceedings of Annual Meeting, Japan Association for Fire Science and Engineering, pp.327-328 (2016) 